\title{
REAL ESTATE PRICES IN THE CZECH REPUBLIC: BEHAVIORAL APPROACH
}

\author{
Eduard Hromada \\ Czech Technical University in Prague, Czech Republic \\ eduard.hromada@fsv.cvut.cz
}

\begin{abstract}
The article deals with the analysis and evaluation of the selected economic, social and technical parameters of real estate in the real estate market in the 119 largest cities of the Czech Republic. These cities have been selected because there is enough turnover in the real estate market. This paper will examine the relationship between the market value of property and market value of rent. The following economic and social parameters will be examined: average annual rental yield, average number of months needed to pay for an apartment, share of people in distraint, numbers of completed apartments per 1000 inhabitants per year, distance from the capital, average wages, and population migration rate. The following econometric and statistical methods are used in the article - linear regression, logarithmic regression and calculation of correlation coefficients. To obtain the input data, the software EVAL was used. EVAL software was developed by the author of this paper. EVAL is able to automatically collect all offers for sale and lease of properties in the Czech Republic that have been published on the Internet. The software has been running continuously since 2007. Data are collected and analysed from all cities in the Czech Republic in monthly periods. Every six months the database of the software expands by more than 750000 price offers from the Internet on purchase or rent of flats, houses, commercial real estate and allotments. Recently, the author extended the functionality of the software, so that it is also able to retrieve data from the real estate cadastre. The presented results in this paper follow the previous research of the author in this area.
\end{abstract}

Keywords: market value, real estate, regression analysis, correlation coefficient, rural development.

\section{Introduction}

Market value of a real estate property is influenced by many technical, economic and social factors, which also change in time. Among the most influential parameters is location, because two real estate properties, which are hypothetically identical in value, may differ dramatically in their market prices. Another important price changer may be constructional and technical status of the building, as well as its age, its location within a municipality, surroundings, accessibility of services, public transportation, mortgage options, type of ownership, current economics, and other. This paper explores the dependence of the market price on given technical, economic, and social factors.

\section{Literature review}

A similar topic was explored, for example, in the referenced paper [1]. This paper aims at studying housing vulnerability in relation to the real estate market by identifying possible indicators and spatially analysing their influence on property prices. Whereas the referenced paper [2] elaborates on methods of automated data acquisition based on web mining, review methods of econometric spatial modelling with impact of proximity in order to deduct efficiency parameters within different categories. Paper [3] focuses on lowering prices of real estate property with each extra minute of commuting to the centre of the capital. It analyses different neighbourhoods of Prague. A similar topic has also been explored by the author of this article, when he analysed relations between the average market value of property for sale for $\mathrm{m} 2$ of floor space, its distance from the central business district (CBD) in $\mathrm{km}$, accessibility of CBD using mass transportation in minutes spent in given form of transport and accessibility of CBD using a passenger car expressed in minutes spent in given form of transport [4]. Papers [5] and [6] discuss the life-cycle cost analysis in relation to the building's value assessment. Study [7] explores the influence of accessible railway or motorway connection on the market value of a property. Both positive and negative externalities of the infrastructure are explored (e.g., transportation stops, motorway exits among the positive and crossroads or railway crossings among the negative). Paper [8] studies the housing market in Florida. Various factors are considered, such as the number of sales, employment rate, interest rate, GDP, inflation rate, hurricane strikes, etc. Historical data of the most influential factors are analysed.

\section{Methodology}

As input for this paper, data created by software EVAL were used. EVAL is a tool developed and constantly upgraded by the author of this paper. It is capable of automatic collection of all real estate 
price bids (both for sale and rent) within the Czech Republic, as they were published online. Data are collected and analyzed for all cities of the Czech Republic in regular monthly periods. EVAL has been running continually since 2007. For a better idea of the amount of data processed, let us state that during the second half of 2018 the software database contained over 750,000 new entries of sale or rental price bids on apartments, houses, commercial spaces or plots of land. The acquired data help analyze and describe the behavior of real estate market, its changes and trends on the grounds of verifiable data collection.

The paper uses regressive analysis to identify the relation between the market selling prices for $\mathrm{m}^{2}$ of floor space, rent prices for $\mathrm{m}^{2}$ of floor space, and other technical, economic and social factors.

The following parameters have been explored:

- relation between the selling price for $\mathrm{m}^{2}$ of floor space and rent price for $\mathrm{m}^{2}$ of floor space in an average apartment in the Czech Republic,

- relation between the selling price for $\mathrm{m}^{2}$ of floor space of an average apartment and average net annual yield of rent,

- relation between the number of months necessary to pay for an average apartment with the floor space of $50 \mathrm{~m}^{2}$ and potential annual rent yield,

- relation between the number of months necessary to pay for an average apartment with the floor space of $50 \mathrm{~m}^{2}$ and selling price of property,

- relation between the ratio of debtors in distraint in given location and average annual rent yield in the same city,

- relation between the number of completed apartments per 1000 inhabitants per 1 year and average selling price for $\mathrm{m}^{2}$.

The calculation included 119 municipalities in the Czech Republic, chosen according to their numbers of inhabitants. The largest analysed city is the capital Prague with its 1,272,690 inhabitants, and the smallest analysed city is Sušice with 11,331 inhabitants. Regressive analysis could have been executed even for a larger scale of municipalities. However, in small municipalities, the data collection may not be sufficient for analysis. Therefore, only cities with a sufficient number of price bids have been analysed in order to ensure statistically valid research.

The Czech Statistics Office data have been used, namely input concerning the number of completed apartments in individual regions in 2016, see https://www.czso.cz/csu/czso/15-stavebnictvibytova-vystavba-j6xw4fuwcx. Further, the paper makes use of selected demographic data in individual regions in 2016, see https://www.czso.cz/csu/czso/4-obyvatelstvo-gaeif0qn54. And also employee numbers and gross wages, as published in CZ-NUTS for the second quarter of 2018, see https://www.czso.cz/csu/czso/cri/prumerne-mzdy-2-ctvrtleti-2018. To calculate the distances between the capital Prague and other cities among the 119 municipalities, the online map has been accessed at https://mapy.cz/. This paper makes use of road distances as used by car transport. To analyse the number of debtors in distraint, another application was used, accessible at http://mapaexekuci.cz/index.php/mapa-2/. Data which we used are valid for 2017. In all the instances, the latest accessible data were collected (hence the period 2016-2018).

It has been found that the relation between the market price of a real estate and the described price-influencing parameters may be expressed by means of linear regression or possibly logarithmic regression. Linear regression represents approximation of given values in a line by the method of smallest squares. Such line is expressed by the following equation:

$$
y=b_{1} x+b_{2},
$$

where optimal values are found for coefficients $b_{1}$ and $b_{2}$.

Logarithmic regression is a specific case of linear regression, where the data set is prolonged by logarithmic function:

$$
y=b_{1} \cdot \ln (x)+b_{2}
$$




\section{Results and discussion}

Figure 1 expresses the relation between the sale prices for $\mathrm{m} 2$ and rent prices for $\mathrm{m} 2$ of an average apartment in the Czech Republic. It shows that there is a high correlation between the sale and rent prices of real estate. The more expensive the property is to be purchased, the higher value of rent can be expected.

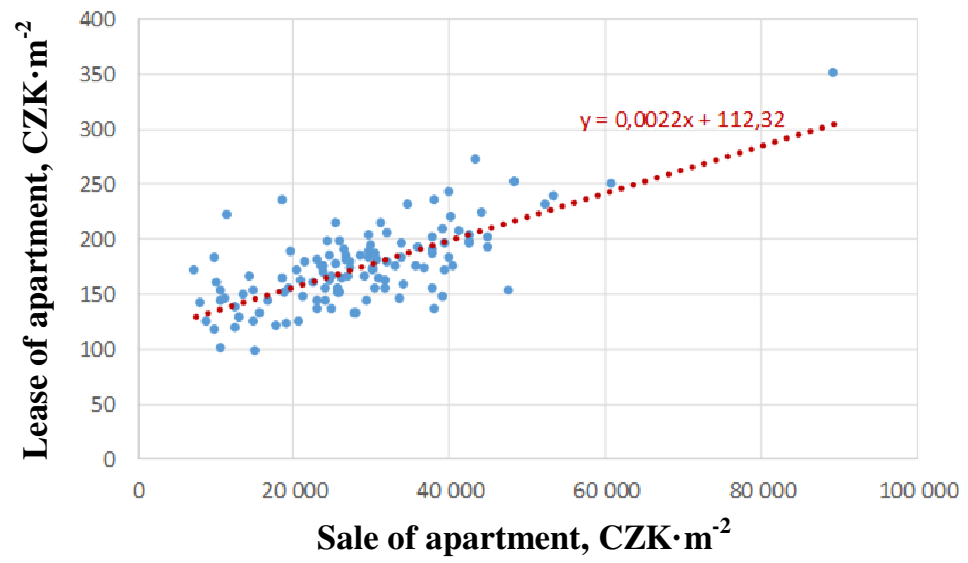

Fig. 1. Dependence between selling price of apartment per $\mathbf{m}^{2}$ and rental price of apartment per $\mathrm{m}^{2}(1 \mathrm{EUR}=25.7 \mathrm{CZK})$. Data source: Software EVAL

Figure 2 shows the relation between the selling price for $\mathrm{m} 2$ of an average apartment in the Czech Republic, and average net rental yield. The calculation of average annual rental yield uses average model prices of apartments for rent and for sale. It takes into account the costs of obtaining and equipping the property, property taxes, income tax, property insurance, maintenance and refurbishing and maintaining a risk fund.

The relation shows that with a higher selling price of property, the annual rent yield drops. This is caused by the fact that selling prices of real estate in the Czech Republic show markedly bigger difference than the income levels and rental prices of property. Therefore, it is more efficient for longterm investment to focus on real estate outside the capital, where selling prices are lower. Selling prices of real estate property in Prague no longer correspond with the city residents' incomes. Potential rental price of a property is closely related to accessible income levels. Selling prices, on the other hand, are closely related to accessibility of a mortgage.

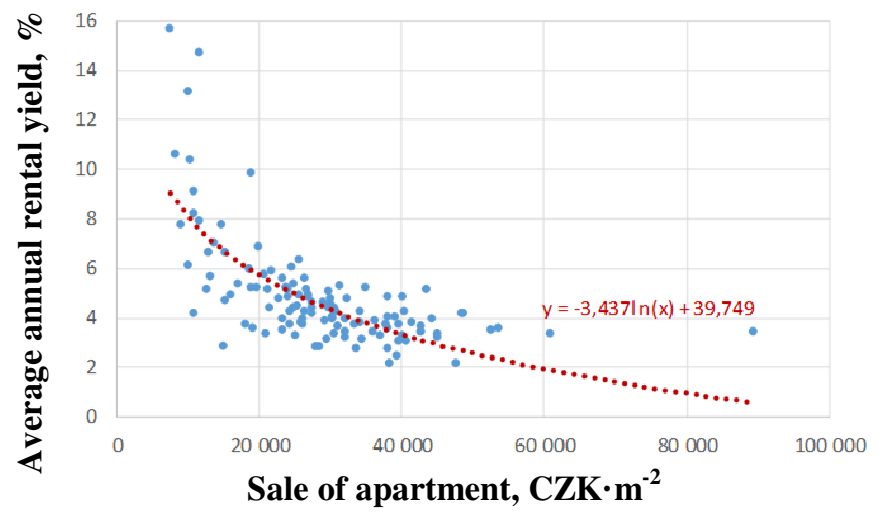

Fig. 2. Dependence between selling price of apartment per $\mathbf{m}^{2}$ and average annual rental yield $(1 \mathrm{EUR}=25.7 \mathrm{CZK})$. Data source: Software EVAL

Figure 3 and Figure 4 show the relation between the number of months necessary for payment of an average apartment with floor space of $50 \mathrm{~m} 2$, average annual rental yield and the selling price of property. Varied levels of rent and sale prices in different cities are taken into account, as there are differences in income levels in different regions of the republic. The descriptor "number of months necessary for payment of an average apartment with floor space of $50 \mathrm{~m}^{2,}$ describes a scenario, in 
which full monthly wages are used to pay for the given apartment. Among the total costs of average apartments, all necessary taxes are accounted for, as well as the budget of CZK 250000 (EUR 9 727). The budget has been calculated as the average price of equipment, additional fees and costs needed before the apartment is fit for use. This shows that Prague and Brno have unambiguously the worst availability of apartments with respect to the market price levels vs. income levels.

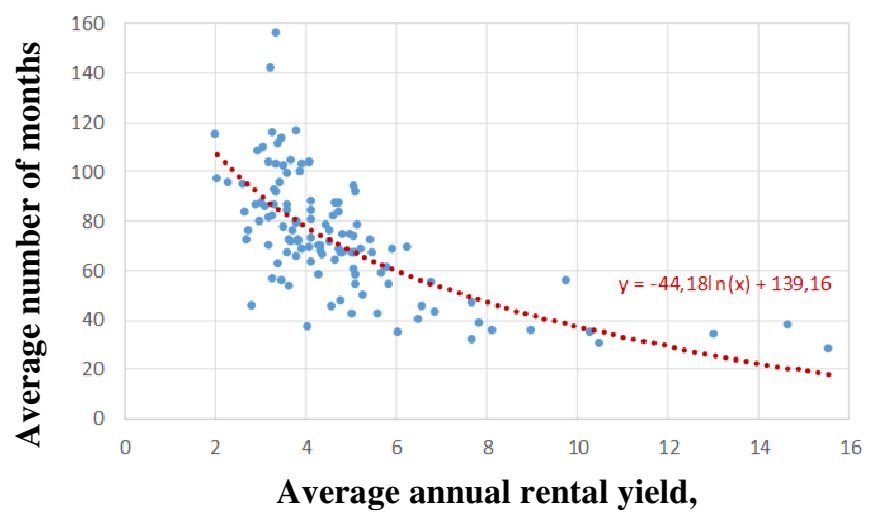

Fig. 3. Dependence between average annual rental yield and average number of months needed to pay for apartment. Data source: Software EVAL, the Czech Statistical Office

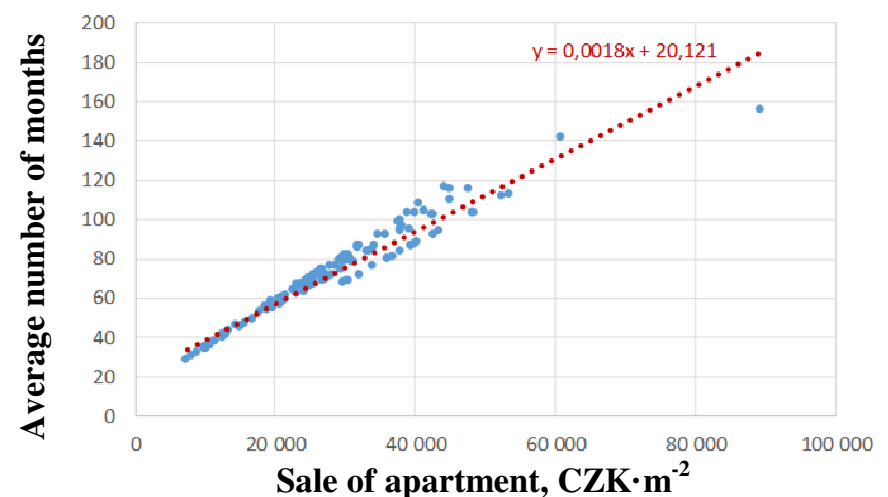

Fig. 4. Dependence between selling price of apartment per $\mathbf{m}^{2}$ and average number of months needed to pay for apartment $(1 \mathrm{EUR}=25.7 \mathrm{CZK})$. Data source: Software EVAL, the Czech Statistical Office

Figure 5 depicts the relation between the number of people in distraint in a given city and the average annual rent yield in the same place. It shows that a higher number of distraints leads to higher rent yields. The reason is the fact that selling prices of property in these regions are usually quite low, while rents remain on the average level. The case may even be that rents are disproportionally higher, when compared to locations without social issues.

This shows the extremely bad practice of abuse of social allowances, which is caused by some of those, who rent apartments in poverty stricken areas. Allowances are used to pay for overpriced rental apartments.

Figure 6 shows a correspondence between the number of completed apartments per 1,000 inhabitants per year and average selling price for $\mathrm{m} 2$. The media often state that very few new apartments are being built in Prague, Brno, and other regional centres. However, these locations have the highest proportion of new apartments per 1,000 inhabitants. This may be the result of very high price levels in these locations and consequential high motivation of developers to complete new apartments in the locations which offer highest revenue. 


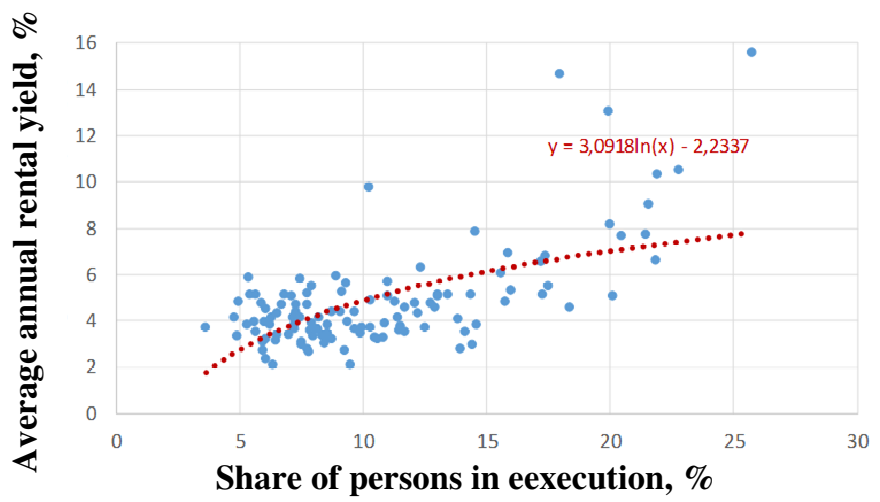

Fig. 5. Dependence between average annual rental yield and share of individuals in distraint. Data source: Software EVAL, the Czech Statistical Office

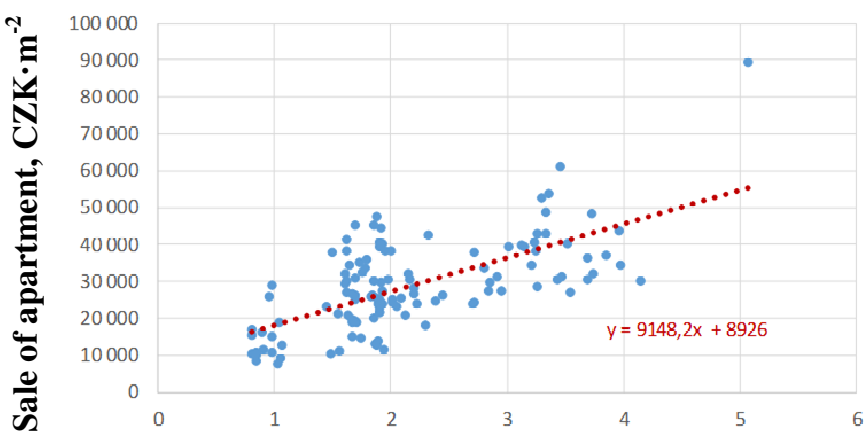

Number of completed apatments per 1000 inhabitants per year

Fig. 6. Dependence between numbers of completed apartments per 1000 inhabitants per year and selling price of apartment per $\mathbf{m}^{2}(1 \mathrm{EUR}=25.7 \mathrm{CZK})$. Data source: Software EVAL

It has been stated that there exists a correlation between the market price of a real estate property, rental price of the same, number of months necessary to pay for average apartment, number of people in distraint, average annual rent yield and the number of completed apartments per 1,000 inhabitants in one year. Table 1 shows the calculations of correlation coefficients of all the aforementioned factors.

\section{Correlation coefficients of researched parameters}

Table 1

\begin{tabular}{|c|c|c|c|c|c|}
\hline Figure & Parameter 1 & $\begin{array}{c}\text { Unit of } \\
\text { measure }\end{array}$ & Parameter 1 & $\begin{array}{c}\text { Unit of } \\
\text { measure }\end{array}$ & $\begin{array}{c}\text { Correlation } \\
\text { coefficient }\end{array}$ \\
\hline 1 & Sale of apartment & $\mathrm{CZK} \cdot \mathrm{m}^{-2}$ & Lease of apartment & $\mathrm{CZK} \cdot \mathrm{m}^{-2}$ & 0.713 \\
\hline 2 & Sale of apartment & $\mathrm{CZK} \cdot \mathrm{m}^{-2}$ & Average annual rental yield & $\%$ & -0.585 \\
\hline 3 & Average annual rental yield & $\%$ & Average number of months & month & -0.632 \\
\hline 4 & Sale of apartment & $\mathrm{CZK} \cdot \mathrm{m}^{-2}$ & Average number of months & month & 0.970 \\
\hline 5 & Share of people in distraint & $\%$ & Average annual rental yield & $\%$ & 0.671 \\
\hline 6 & \begin{tabular}{|c|} 
Numbers of completed \\
apartments per 1000 inhabitants \\
per year
\end{tabular} & apartment & Sale of apartment & $\mathrm{CZK} \cdot \mathrm{m}^{-2}$ & 0.632 \\
\hline- & $\begin{array}{l}\text { Population increase per } 1000 \\
\text { middle-class residents }\end{array}$ & resident & Sale of apartment & $\mathrm{CZK} \cdot \mathrm{m}^{-2}$ & 0.589 \\
\hline- & $\begin{array}{c}\text { Population increase per } 1000 \\
\text { middle-class residents }\end{array}$ & resident & Lease of apartment & $\mathrm{CZK} \cdot \mathrm{m}^{-2}$ & 0.523 \\
\hline- & Distance from the capital city & $\mathrm{km}$ & Sale of apartment & $\mathrm{CZK} \cdot \mathrm{m}^{-2}$ & -0.331 \\
\hline- & $\begin{array}{l}\text { Average percentage of new } \\
\text { apartments offered for sale }\end{array}$ & $\%$ & Sale of apartment & $\mathrm{CZK} \cdot \mathrm{m}^{-2}$ & 0.623 \\
\hline
\end{tabular}

Data source: Software EVAL, The Czech Statistical Office. 


\section{Conclusions}

During the research, relations have also been found for population growth or depopulation, distance of individual regional cities from Prague, ratio of new and old apartments for sale, price levels of sale or rent of apartments. Correlation coefficients for these factors are also stated in Table 1. These factors show a lower rate of price influence. That may be caused by specific structure of the Czech real estate market with Prague as the dominant capital, which continually raises the number of its inhabitants at the expense of other regions. This causes various negative results with respect to real estate prices and financial accessibility of housing. Moreover, there are regions within the Czech Republic, where the amount of real estate purchases is lower than average for a given amount of inhabitants. In some cases, the regions are struck by social problems, which lead to young people's walk-out towards regional centres. It has been found that the primary determinant that affects the real estate market is the price per $\mathrm{m}^{2}$ of real estate.

\section{Acknowledgements}

This work was supported by the Grant Agency of the Czech Technical University in Prague, grant No. SGS17/121/OHK1/2T/11.

\section{References}

[1] Barreca A., Curto R., Rolando D. Housing vulnerability and property prices: Spatial analyses in the turin real estate market Sustainability (Switzerland), 10(9), 2018, doi:10.3390/su10093068

[2] Muggenhuber G. Data mining and analytics for real-estate applications, 2019. doi: 10.1007/978-3319-72434-8_11

[3] Kaderabkova B., Lukavec M. How much does a minute of commuting time cost? An examination of property prices in relation to distance to the city center in Prague, Czech Republic The Civil Engineering Journal. 2017, pp. 555-567.

[4] Hromada E. Analysis of relationship between market value of property and its distance from center of capital The Engineering for Rural Development, 17, 2018, pp. 646-651.

[5] Heralova S.R. 2007 Building's value assessment using the utility and the LCC CESB 2007 Prague International Conference. ISBN 978-80-903807-8-3

[6] Matejka P., Vitasek S. Comparison of different cost estimation methods with use of building information modelling (BIM) Engineering for Rural Development, 17, 2018, pp. 843-849.

[7] Seo K., Salon D., Kuby M., Golub A. Hedonic modeling of commercial property values: Distance decay from the links and nodes of rail and highway infrastructure Transportation, 2018, pp. 1-24.

[8] Aderibigbe T., Chi H. Investigation of Florida housing prices using predictive time series model ACM International Conference Proceeding Series, 2018, doi:10.1145/3219104.3229253 